\title{
Neurotoxic effects of bisphenol A on SH-SY5Y neuroblastoma cells via nitric oxide
}

\author{
Beyza AYAZGÖK 1 (D) , Tuba TÜYLÜ KÜÇÜKKILINÇ ${ }^{\text {* }}$ (D) \\ 1 Department of Biochemistry, Faculty of Pharmacy, Hacettepe University, Ankara, Turkey \\ * Corresponding Author. E-mail: ttuylu@hacettepe.edu.tr (T.T.K.); Tel. +90-312-305 1499.
}

Received: 16 October 2018/ Revised: 19 December 2018 / Accepted: 19 December 2018

\begin{abstract}
Bisphenol A (BPA, 2,2-bis(4-hydroxyphenyl)propane)polycarbonate is an industrial component frequently used as an additive in the construction of epoxy resin and other non-polymer plastics. In this study cytotoxicity of low dose BPA $(0.01 \mu \mathrm{M}-100 \mu \mathrm{M})$ and NO levels in SH-SY5Y cells were assessed together to determine whether there is a correlation between of them. MTT Cytotoxicity assays were performed by applying BPA at increasing doses $(0.01 \mu \mathrm{M}-100 \mu \mathrm{M})$ for 8, 24, 72 hours. Measurements to determine the nitric oxide (NO) levels of the cells, were made using the Griess method at the same time intervals and at the equal doses with BPA. It is found that percentage viability values in SH-SY5Y cells treated with $100 \mu \mathrm{M}$ BPA for 8 hours, is reduced statistically significant compared to control groups $(\mathrm{p}<0.001)$. A significant correlation was found between cytotoxicity results and NO levels of cells treated BPA $(0.01 \mu \mathrm{M}-100 \mu \mathrm{M})$ for 8 and 72 hours $(\mathrm{p}<0.01, \mathrm{p}<0.001$ respectively). Neurotoxic effects of low dose BPA exposure on SH-SY5Y cells may be explained with increase in the levels of $\mathrm{NO}$ as a result from different parameters. One of these parameters could be a disorder in the synthesis of nNOS on different stages such as transcription and translation.
\end{abstract}

KEYWORDS: Bisphenol A; nitric oxide; cytotoxicity; neurotoxicity.

\section{INTRODUCTION}

Bisphenol A (BPA, 2,2-bis(4-hydroxyphenyl) propane) polycarbonate is an industrial component frequently used as an additive in the construction of epoxy resin and other non-polymer plastics [1]. Due to the large number of applications of bisphenol-A (BPA), the human exposure ways are multiple. BPA exposure occurs in a large number of ways, such as foodborne or natural water sources, air, dust, thermal paper, other paper types, cosmetics, dental materials, medical devices and other health practices [2].

Effects of BPA on adult brain growing is examined with many in-vivo and in-vitro studies. Yokosuka et al described that high dose (500 $\mu \mathrm{g}$ / day) BPA causes changes in dendritic and synaptic development [1]. Due to the lipophilic structure of BPA allows to transition blood-placenta and blood- brain barrier. BPA exposure is also important in lactation [3]. Literally it is reported that low dose BPA exposure had adverse effects on brain cells and altered the learning and memory ability of adolescent mice[4]. Unlike adult exposure, BPA exposure at early embryonic / fetal / neonatal development of central nervous system (CNS) has been reported to alter brain physiology [5].

Nitric oxide (NO), is a free radical has a short half-life plays an important role in many biological processes. Nitric oxide is a gaseous neurotransmitter and/or neuromodulator, which is synthetized from Larginine with a reaction which nitric oxide synthases (nNOS) play a role [6,7]. NO is an essential mediator in the relaxation of the vascular smooth muscles in the gastrointestinal tract, respiratory system and cavernous tissues [8]. NO has different biological effects at physiological concentrations in almost all organ systems. NO supports the various functions in the central nervous system, including the formation of memory, as a neurotransmitter [9]. NO is a compound that acts directly as a neurotransmitter and regulates the release of classical neurotransmitters in many areas of the brain. Indirectly, NO stimulates adjacent glutaminergic neurons in the nucleus accumbens and provides acetylcholine release [10]. In telencephalon and cerebellum, NO plays a significant role in the regulation of synaptic plasticity, which contributes to cognitive functions such as memory. Additionally in diencephalon $\mathrm{NO}$ is the most important compound to regulate

How to cite this article: Ayazgök B, Tüylü Küçükkılınç T. Neurotoxic effects of bisphenol A on SH-SY5Y neuroblastoma cells via nitric oxide. J Res Pharm. 2019; 23(3): 354-359. 
neurosecretuar activity of hypothalamus. In mesencephalon, NO regulates many functions in the formation and control of the sleeping pattern [11].

In this study, cytotoxicity assays were performed by applying BPA at increasing doses $(0-100 \mu \mathrm{M})$ for $8,24,72$ hours to understand the toxicity of BPA in neuroblastoma cells. Measurements to determine the nitric oxide (NO) levels of the cells, were made using the Griess method at the same time intervals and at the same doses with BPA. Cytotoxicity results and NO levels were assessed together to determine whether there is a correlation between viability and NO level of cells. This relationship will facilitate understanding BPA cytotoxicity and BPA effects on the physiology of central nervous systems.

\section{RESULTS}

\subsection{Viability results}

Percentage viability values of SH-SY5Y cells treated with increased concentrations of BPA $(0-100 \mu \mathrm{M})$ at different hours are shown below as Figure 1.

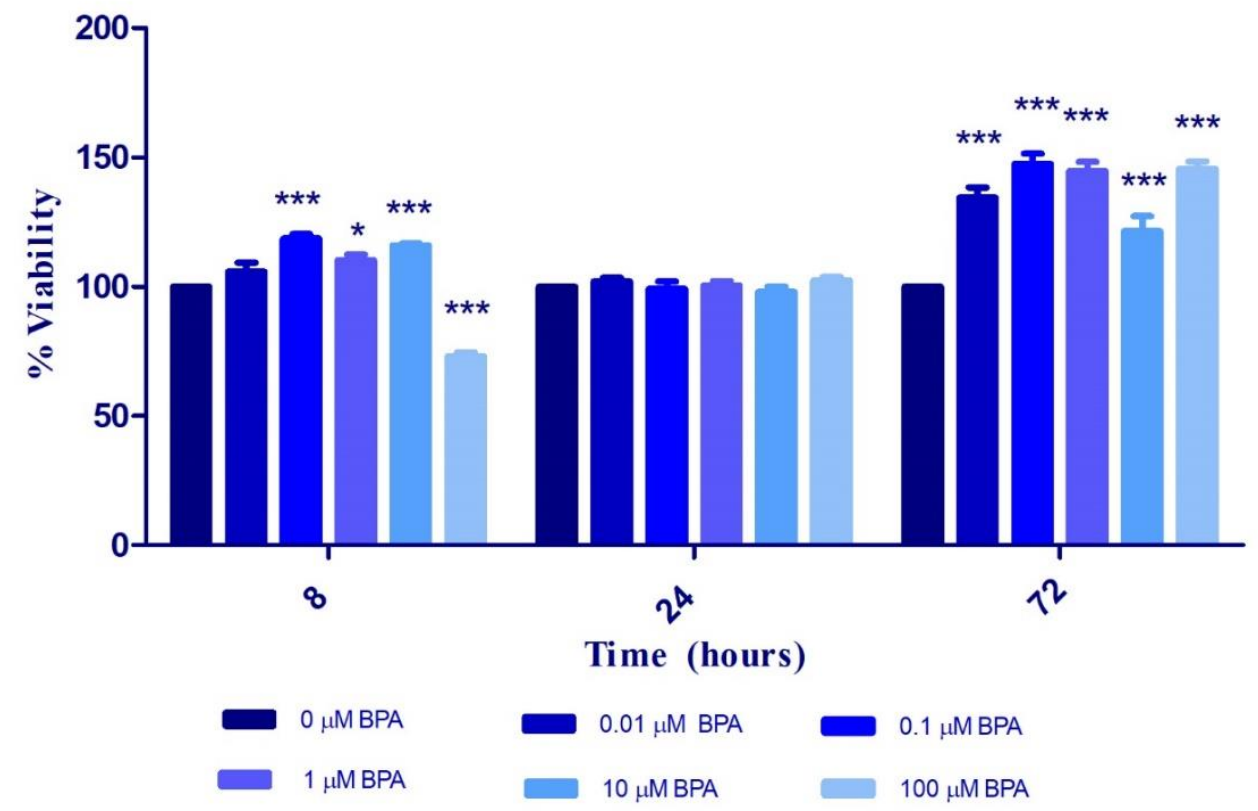

Figure 1. Percentage viability values of SH-SY5Y cells treated with increased concentrations of BPA $(0-100$ $\mu \mathrm{M})$ at different hours $\left({ }^{*} \mathrm{p}<0.05,{ }^{* * *} \mathrm{p}<0.001\right)$.

The percentage viability values in SH-SY5Y cells treated with BPA at increasing concentrations was examined, the $0.1 \mu \mathrm{M}, 10 \mu \mathrm{M}$ BPA application for a period of 8 hours resulted in a significant increase compared to the control group at viability; $100 \mu \mathrm{M}$ BPA administration significantly reduced the viability percentage $\left({ }^{* * *} \mathrm{p}<0.001\right)$. No significant changes were observed with BPA administration at increasing concentrations for 24 hours in viability percentages of SH-SY5Y human neuroblastoma cells. $10 \mu \mathrm{M}$ BPA application in the same time zone was found to statistically reduce the viability percentage of cells. $1 \mu \mathrm{M}, 10$ $\mu \mathrm{M}$ and $100 \mu \mathrm{M}$ BPA treatment is changed viability percentage of cells statistically significantly $\left.{ }^{* * *} \mathrm{p}<0.001\right)$.

Treatment with increased concentrations of BPA for 72 hours were observed to increase percentage cell viability values statistically significantly at each concentration $\left({ }^{* *} \mathrm{p}<0.001\right)$. The highest increase in percentage viability value was recorded with $0.1 \mu \mathrm{M}$ BPA application.

\subsection{NO Levels}

Percentage NO levels of SH-SY5Y cells treated with BPA at increasing concentrations obtained by the Griess method were evaluated. Percentage NO values of SH-SY5Y cells treated with increased concentration BPA $(0-100 \mu \mathrm{M})$ at different hours is presented in Figure 2. It is observed that $100 \mu \mathrm{M}$ BPA administration increased \% NO for 8 hours significantly. Other doses of BPA administration have been observed to slightly reduce the NO levels of cells. A modest increase in \% NO levels of cells was observed by administration of all BPA doses except $100 \mu \mathrm{M}$ at 24 hours. BPA administration at increasing concentrations $(0-100 \mu \mathrm{M})$ for $72 \mathrm{~h}$ decreased \% NO levels of SH-SY5Y cells significantly. 


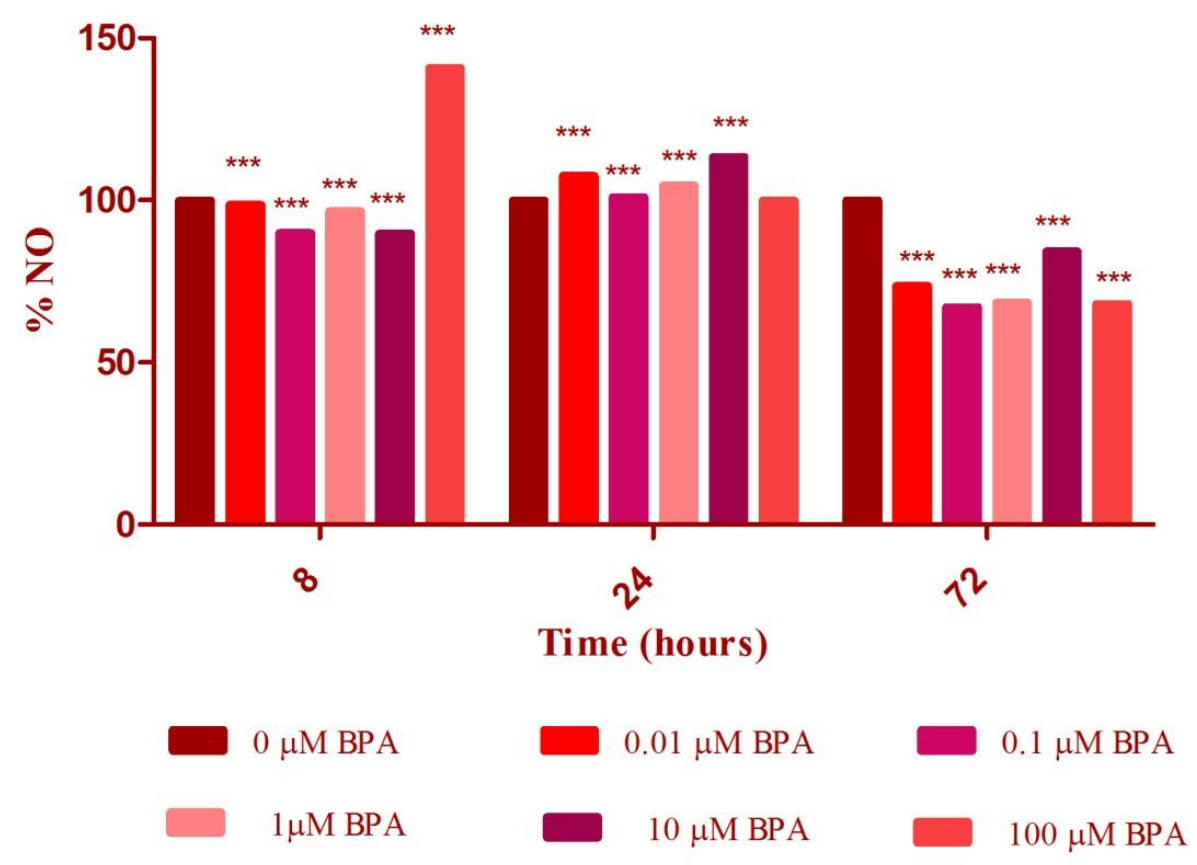

Figure 2. \% NO values of SH-SY5Y cells treated with increased concentration BPA $(0-100 \mu \mathrm{M})$ at different hours $(* * * \mathrm{p}<0.001)$.

The percentage viability data obtained by the MTT cytotoxicity assay and the\% NO levels measured by the Griess method were evaluated together and the correlation graph obtained with the data is shown in Figure 3. A significant correlation was found between cytotoxicity results and NO levels of cells treated with BPA $(0-100 \mu \mathrm{M})$ for 72 hours. $(\mathrm{p}<0.05$, spearman $\mathrm{r}=-1.000)$.
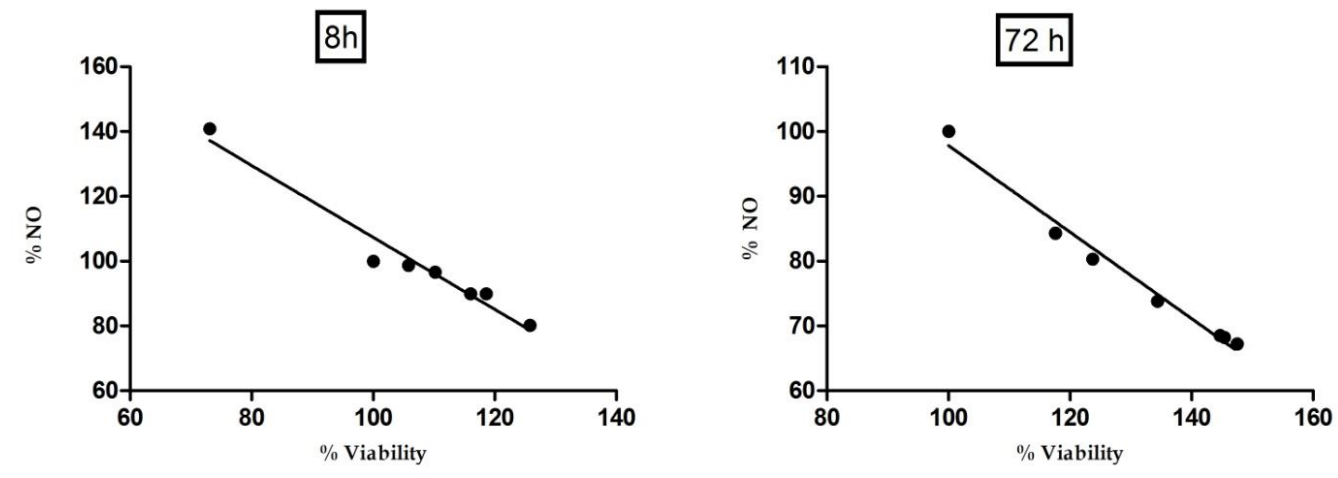

Figure 3. Correlation graph of MTT results and \% NO values in SH-SY5Y cells treated with BPA (0-100 $\mu \mathrm{M})$ for 8 and 72 hours. $R^{2}$ values of correlation graph is $0.96,0.98$ respectively.

\section{DISCUSSION}

When the results were evaluated, \% NO increase was determined in parallel with the decrease in percentage viability of SH-SY5Y cells. The increase in NO level led to an increase in cytotoxicity. When percentage viability and \% NO data of SH-SY5Y cells were evaluated, it was observed that there was a significant negative correlation between percentage viability and \% NO level with 8,72 hours BPA administration $(\mathrm{p}<0.01, \mathrm{p}<0.001)$.

Negative correlation explain that increased NO level may effect cell viability. Parallel to our results, previous studies show much evidence that $\mathrm{NO}$ can effect cell viability by inducing cell death. A prevalent 
view pointed that $\mathrm{NO}$ exerts cytotoxic effects in diverse cell types by reacting with superoxide and thereby generating the highly reactive free radical peroxynitrite, which causes non-specific oxidative DNA, protein and lipid damage [12-14]. These damage also triggers downstream signaling pathways and gene expression, which might lead to apoptosis or necrosis [15]. Previous works in literature have demonstrated that NO induces apoptosis in a concentration and time-dependent manner in SH-SY5Y neuroblastoma cells [16, 17].

Our results distincly show that different doses $(0-100 \mu \mathrm{M})$ of BPA administered for different period may change viability and NO levels of SH-SY5Y neuroblastoma cells. Our group recently published that NO plays a role in cytotoxicity of low dose BPA in SH-SY5Y neuroblastoma cells [18]. Additionally, it has been shown that NO induces cell death mechanisms in other type of neuroblastoma cell lines [19, 20]

These observations clarify the fact that doses of BPA at levels $0.05 \mathrm{mg} / \mathrm{kgbody}$ weight/day, which for a long time was thought by EFSA to be safe, is toxic for the SH-SY5Y neuroblastoma cells. On the other hand, it is known that NO has directional and undirectional functions in the regulation of the several systems such as gastrointestinal and central nervous systems. Neurotoxic effects of low dose BPA exposure on SH-SY5Y neuroblastoma cells may be explained with increase in the levels of $\mathrm{NO}$ as a result from different parameters. Previous report of Ayazgok et al showed that nNOS mRNA level was not changed by low dose BPa treatment in SH-SY5Y neuroblastoma cells [18]

\section{CONCLUSION}

In this research we determined viability and NO levels of SH-SY5Y cells treated with BPA at different concentrations and time. Our findings display the potential risks of daily BPA exposure and remind us to focus more carefully to the potential and expanded of environmental BPA exposure in humans, especially in children and young adults.

Further research is needed to enlighten the mechanism of increased NO levels due to BPA exposure in SH-SY5Y cells.

\section{MATERIALS AND METHODS}

\subsection{Cell culture}

SH-SY5Y human neuroblastoma cells were incubated in an incubator containing DMEM medium containing $10 \% \mathrm{HI} \mathrm{FBS,} 1 \%$ L-glutamine, $0.5 \%$ ciprofloxacin and $0.01 \%$ tazobactam at $37^{\circ} \mathrm{C}$ and $5 \% \mathrm{CO}_{2}$. The viability and proliferation of the cells were examined in light microscopy at frequent intervals and the media were changed day by day. Cells were passaged when observed to reach $80 \%$ of the fullness. The media was aspirated, and the cells were washed with phosphate buffered saline (PBS) pH 7.4. A trypsin-EDTA solution of $0.25 \%$ was added to the cells and incubated at $37^{\circ} \mathrm{C}$ for $2-3$ minutes. After a few minutes DMEM was added and centrifuged at room temperature for 10 minutes at $250 \times \mathrm{g}$. After centrifugation, the supernatant was aspirated and DMEM was added to the cells. Pellets were dissolved homogenously then they were taken to new flasks according to the determined dilution ratio.

\subsection{Cell count}

Cells were transferred to sterile, polarized tubes and centrifuged at room temperature for 10 minutes at 250 xg. Pellets were dissolved in DMEM and diluated with trypane blue for count the cellls on Thoma slide. Dead cells collect paint on the basis of preserving membrane integrity.Viable cells were counted in light microscopy. Total number of cells was determined using the formula given below.

Total cell number $=$ Counted cell number $\times 10,000 \times$ dilution factor

\subsection{MTT Assay}

Cell viability was determined using a Thiazolyl Blue Tetrazolium Bromide (3-(4,5-Dimethyl-2thiazolyl)-2,5-diphenyl-2H-tetrazolium bromide (MTT) assay. SH-SY5Y cells was seeded at 5000 cells per well in 96-well plates and cultured in DMEM supplemented with $10 \% \mathrm{FBS}$ at $37^{\circ} \mathrm{C}$ with $5 \% \mathrm{CO}_{2}$. Plate was preincubated for 24 hours in $\mathrm{CO}_{2}$ incubator. SH-SY5Y cells were treated with various concentrations ( $1 \mu \mathrm{M}-100$ $\mu \mathrm{M})$ of BPA. Plate was incubated for 48 hours. After incubation $10 \mu \mathrm{L}$ MTT reagent ( $5 \mathrm{mg} / \mathrm{ml}$; Sigma-Aldrich) was added to each well. MTT formazan crystals was dissolved by the addition of $100 \mu \mathrm{L}$ DMSO. The absorbance values at $690 \mathrm{~nm}$ and $570 \mathrm{~nm}$ were determined using Biotek Power Wave XS microplate reader. Relative cell viability estimated by comparing absorbance of treated group and untreated control group. The 
percentage of cell viability was calculated as percentage cell viability $=($ Ac $690 \mathrm{~nm}-$ Ac $570 \mathrm{~nm}){ }^{*} 100 /($ As $690 \mathrm{~nm}-\mathrm{As} 570 \mathrm{~nm}$ ) where Ac is the absorbance of the control group and As is the absorbance of the sample.

\subsection{Griess reaction method}

The effect of different concentrations ( $10 \mathrm{nM}-100 \mu \mathrm{M}$ ) of BPA on NO level in SH-SY5Y cells was evaluated in the medium using the Griess reaction method. $50 \mu \mathrm{l}$ of cultured medium and equal volume of Griess reagent $(1 \%$ sulfanilamide in $5 \%$ phosphoric acid and $0.1 \%$ naphtylethylenediamine dihydrochloride in distilled water) were mixed, and incubated for 20 minutes at room temperature. Absorbance at $540 \mathrm{~nm}$ was established with Biotek Power Wave XS microplate reader. Different concentrations (0-200 $\mu \mathrm{M})$ of sodium nitrite $\left(\mathrm{NaNO}_{3}\right)$ solutions were prepared to quantify the nitrite concentration of medium. Standart curve of sodium nitrite was found to calibrate absorption coefficient. estimated by comparing absorbance of treated group and untreated control group. \% NO concentrations of SH-SY5Y cells were calculated by normalizing according to percentage cell viability of treated group and untreated control group.

Acknowledgements: This study was supported by Research Fund of the Hacettepe University (Project Number: THD2015-6821).

Author contributions: Concept -B.A., T.T.K.; Design - B.A., T.T.K.; Supervision - T.T.K.; Resource T.T.K.; Materials B.A., T.T.K.;. Data Collection and/or Processing - B.A., T.T.K.; Analysis and/or Interpretation - B.A., T.T.K.; Literature Search - B.A., T.T.K.; Writing - B.A., T.T.K.; Critical Reviews - B.A., T.T.K.

Conflict of interest statement: The authors declared no conflict of interest.

\section{REFERENCES}

[1] Wetherill YB, Akingbemi BT, Kanno J, McLachlan JA, Nadal A, Sonnenschein C, Watson CS, Zoeller RT, Belcher SM. In vitro molecular mechanisms of bisphenol A action. Reprod Toxicol. 2007; 24(2): 178-198. [CrossRef]

[2] Geens T, Aerts D, Berthot C, Bourguignon JP, Goeyens L, Lecomte P, Maghuin-Rogister G, Pironnet AM, Pussemier L, Scippo ML, Van Loco J, Covaci A. A review of dietary and non-dietary exposure to bisphenol-A. Food Chem Toxicol. 2012; 50(10): 3725-3740. [CrossRef]

[3] Negri-Cesi P. Bisphenol A Interaction with brain development and functions. Dose Response. 2015; 13(2): 1559325815590394. [CrossRef]

[4] Zhou Y, Wang Z, Xia M, Zhuang S, Gong X, Pan J, Li C, Fan R, Pang Q, Lu S. Neurotoxicity of low bisphenol A (BPA) exposure for young male mice: Implications for children exposed to environmental levels of BPA. Environ Pollut. 2017; 229: 40-48. [CrossRef]

[5] Doerge DR, Vanlandingham M, Nathan C, Twaddle K, Delclos B. Lactational transfer of bisphenol A in SpragueDawley rats. Toxicol Lett. 2010; 199(3): 372-376. [CrossRef]

[6] Andrew PJ, Mayer B. Enzymatic function of nitric oxide synthases. Cardiovasc Res. 1999; 43(3): 521-531. [CrossRef]

[7] Kopincová J, Púzserová A, Bernátová I. Biochemical aspects of nitric oxide synthase feedback regulation by nitric oxide. Interdiscip Toxicol. 2011; 4(2): 63-68. [CrossRef]

[8] Szymanska K, Calka J, Gonkowski S. Nitric oxide as an active substance in the enteric neurons of the porcine digestive tract in physiological conditions and under intoxication with bisphenol A (BPA). Nitric Oxide. 2018; 80: 1-11. [CrossRef]

[9] Itoh K, Yaoi T, Fushiki S. Bisphenol A, an endocrine-disrupting chemical, and brain development. Neuropathology. 2012; 32(4): 447-457. [CrossRef]

[10] Prast H, Tran MH, Fischer H, Philippu A. Nitric oxide-induced release of acetylcholine in the nucleus accumbens: role of cyclic GMP, glutamate, and GABA. J Neurochem. 1998; 71(1): 266-273. [CrossRef]

[11] Calabrese V, Mancuso C, Calvani M, Rizzarelli E, Allan Butterfield D, Giuffrida Stella AM. Nitric oxide in the central nervous system: Neuroprotection versus neurotoxicity. Nat Rev Neurosci. 2007; 8(10): 766-775. [CrossRef]

[12] Lipton SA. Neuronal protection and destruction by NO. Cell Death Differ. 1999; 6: 943. [CrossRef]

[13] Kröncke KD, Fehsel K, Kolb-Bachofen V. Nitric Oxide: Cytotoxicity versus cytoprotection - How, why, when, and where? Nitric Oxide. 1997; 1(2): 107-120. [CrossRef] 
[14] Schulz, JB, Matthews RT, Beal MF. Role of nitric oxide in neurodegenerative diseases. Curr Opin Neurol. 1995; 8(6): 480-486.

[15] Brune B, Knethen A, Sandau KB. Nitric oxide (NO): an effector of apoptosis. Cell Death Differ. 1999; 6(10): 969-975. [CrossRef]

[16] Dhakshinamoorthy S, Sridharan SR, Li L, Ng PY, Boxer LM, Porter AG. Protein/DNA arrays identify nitric oxideregulated cis-element and trans-factor activities some of which govern neuroblastoma cell viability. Nucleic acids Res. 2007; 35(16): 5439-5451. [CrossRef]

[17] Li L, Feng Z, Porter AG. JNK-dependent phosphorylation of c-Jun on serine 63 mediates nitric oxide-induced apoptosis of neuroblastoma cells. J Biol Chem. 2004; 279(6): 4058-4065. [CrossRef]

[18] Ayazgök B, Küçükkılınç T. Low-dose bisphenol A induces RIPK1-mediated necroptosis in SH-SY5Y cells: Effects on TNF- $\alpha$ and acetylcholinesterase. J Biochem Mol Toxicol. 2018; 33(1): e22233 [CrossRef]

[19] Kurt O, Özdal-Kurt, Akçora CM, Özkut M, Tuğlu MI. Neurotoxic, cytotoxic, apoptotic and antiproliferative effects of some marine algae extracts on the NA2B cell line. Biotech Histochem. 2018; 93(1): 59-69. [CrossRef]

[20] Ghatan S, Larner S, Kinoshita Y, Hetman M, Patel L, Xia Z, Youle RJ, Morrison RS. p38 MAP kinase mediates bax translocation in nitric oxide-induced apoptosis in neurons. J Cell Biol. 2000; 150(2): 335-347.

This is an open access article which is publicly available on our journal's website under Institutional Repository at http://dspace.marmara.edu.tr. 